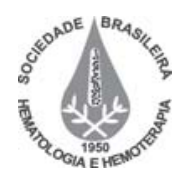

Editoriais / Editorials

\section{Celso Carlos de Campos Guerra}

Milton Artur Ruiz

O editorial deste fascículo, que inicia o volume 30, seria sobre os avanços da Revista Brasileira de Hematologia e Hemoterapia (RBHH) na qual seriam enfatizados aspectos do aumento da periodicidade, agora bimestral, e a perspectiva de edição de novos suplementos temáticos. Da adoção da submissão exclusivamente online dos manuscritos e contribuições, e da avaliação destas sob o novo sistema de gerenciamento de publicações eletrônico, além dos desafios que a Revista deverá enfrentar e terá de suplantar no decorrer deste ano. Porém, o falecimento de Celso Carlos de Campos Guerra, em dois de fevereiro, ultrapassou as preocupações com estes temas e me impeliu a escrever sobre a atuação de Celso na RBHH e de relatar alguns aspectos de sua personalidade guerreira, mas terna, que tive a honra de compartilhar, e da sua importância para a hematologia brasileira.

Ex-presidente da SBHH, da APM, professor da EPM são simples títulos a ilustrar o seu currículo, mas considero que a sua principal função, e a maior delas, foi a de abrir espaço aos mais jovens além da sua capacidade inegável de agregar pessoas em torno de idéias. Isto é palpável e está evidenciado na organização e instalação do Centro de Hematologia de São Paulo, afora das inúmeras participações em diretorias de entidades, da condução da luta da erradicação da Doação remunerada de sangue em nosso país, da Cruzada contra a Anemia e de muitos outros projetos de cunho político e social.

Em relação à RBHH, hoje sedimentada como o órgão científico da hematologia brasileira, Celso teve participações pontuais e cruciais desde o seu início e que remontam ao passado. Em 1981, no Congresso Brasileiro de Fortaleza se achegou a mim e, da sua maneira habitual e coloquial disse: "te coloquei numa fria"! Instado pela observação acabava de ser convocado a ser o secretário-geral da SBHH com uma incumbência clara de editar o Boletim mensalmente.

Em 1984, com a evolução da Sociedade Brasileira de Hematologia e Hemoterapia (SBHH), bancou, com outros colegas, a transformação do Boletim em uma revista de cunho científico. Em 1987 interferiu pessoalmente junto à Bireme na indexação da Revista no Index Medicus Latino-Americano (IMLA) e no Lilacs. Participante do Conselho Editorial desde o seu início, elaborou artigos, editoriais, estimulou colegas a escreverem e participarem da Revista. Foi o co-editor e condutor do grupo que editou o primeiro fascículo temático do Boletim da SBHH sobre Benzenismo, assunto que estava em evidência no final da década de 80 e início da década de 90 , fascículo este por demais citado, que abriu caminhos com o seu formato para os atuais fascículos temáticos da RBHH.
Como presidente em exercício da SBHH em 1998, mais uma vez bancou a mudança de título da Revista para o atual por entender que era chegado o momento da revista assumir o seu real papel educativo e científico na Hematologia Brasileira.

Assim, sem aviso e sem nos dar tempo para contestação, foram-se o meu orientador e amigo, e a audácia que permeou o nosso convívio guerreiro ao longo destes 38 anos de vida.

Recebido: $12 / 02 / 2008$

Aceito: 12/02/2008

Editor da Revista Brasileira de Hematologia e Hemoterapia

Correspondência: Milton Artur Ruiz

Avenida Dr. Enéas Carvalho Aguiar 155 - $1^{\circ}$ andar

05403-000 - S.Paulo-SP

milruiz@yahoo.com.br 